\title{
Composition, structure and stratification of laminated cyanobacterial mats in an irrigation canal (Al-Kharj, Saudi Arabia)
}

\author{
T.M. Khoja ${ }^{1}$
}

Keywords : cyanobacterial mats, benthic algae, Tolypothrix distorta, Phormidium tenue, calcareous water.

Three forms of algal mats : subaerial, emersed and submersed, and their species composition, structure and stratification were studied for a period of twelve months (1996-1997) in an irrigation canal at Al-Kharj, Saudi Arabia:

The development of the mats is a continuous process in a gradient fashion from the outlet of a piedmont cave-lake to the end of the canal. The growth maxima occurred at the first weir, which is subject to fast water-current and spray-wetted zone. Mats developed as discrete associations, recognizable by their colour and shape.

Hard lithified, soft and floppy, and thin crust types of mats developed in their respective zones and comprised separate biotic communities. Ecological factors such as the nature of the microhabitat, water-chemistry, fluctuation in water-flow, depth of water column, splashing and temperature may have influenced their formation. The emersed mats with Phormidium tenue were predominant from November to February, whereas the subaerial mats above with Tolypothrix distorta adhere to the canal wall as a permanent feature. The subaerial mat has stromatolite-like morphology and is considered a nuisance to the water and drainage maintenance.

Composition, structure et stratification de tapis de Cyanobactéries dans un canal d'irrigation (Al-Kharj, Arabie Saoudite)

Mots clés : tapis de cyanobactéries, algues benthiques, Tolypothrix distorta, Phormidium tenue, eau calcaire.

La composition, la structure et la stratification de 3 tapis d'algues, subaériens, émergés et submergés, ont été étudiés pendant une période de 12 mois dans un canal d'irrigation à $\mathrm{Al}$ Kharj (Arabie Saoudite).

Le développement des tapis est un processus continu formant un gradient de la sortie d'un lac de caverne à l'extrémité du canal. Le maximum de croissance apparaît à la première rupture de pente, qui est soumise à un courant rapide et continuellement arrosée. Les tapis se développent comme des associations discontinues, reconnaissables à leur couleur et leur forme.

Différentes formes de tapis, soit durs et minéralisés, soit moux et spongieux, soit finement encroûtants, se développent chacun dans leur zone et son constitués de communautés distinctes. La nature du microhabitat, la chimie de l'eau, la fluctuation de l'écoulement d'eau, la profondeur de la couche d'eau, l'aspersion et la température sont des facteurs qui interviennent dans leur formation. Les tapis émergés avec Phormidium tenue prédominaient à partir de novembre à février, tandis que les tapis subaériens avec Tolypothrix distorta adhèrent au mur de canal de manière permanente. Le tapis subaérien a une structure semblable à celle des stromatolites et est considéré comme une nuisance pour l'eau et l'entretien du drainage.

\section{Introduction}

Luxuriant growth of cyanobacterial (cyanophytes) mats are of common occurrence in marine, brackish and calcareous inland waters of Saudi Arabia (Whitton

1. Dept. of Botany \& Microbiology, Faculty of Science, P. O. Box 2455, King Saud University, Riyadh 11451, Saudi Arabia. et al. 1986, Khoja 1987, 1993, 1998, Hussain \& Khoja 1993, Hussain et al. 1996). Calcareous sedimentation in the form of laminated algal mats is broadly known as stromatolites. Stromatolites are defined as «organosedimentary structures produced by some combination of sediment trapping, binding, and precipitation as a result of the growth and metabolic activity of microorganisms, principally cyanophytes» (cyanobacteria, blue-green algae, Walter 1976). Some authors agree with his definition while others restrict the term to li- 
thified laminated structures (Golubic \& Focke 1978). Kendal \& Skipwith (1968) described the relation between cyanobacterial mats and carbonate deposition and reported recent stromatolites from the coastal lagoon of Abu Dhabi. Deposition of gypsum and halite in the form of crystals around filaments in marine cyanobacterial mats in the Persian Gulf has been described by Golubic (1973). Removal of carbonate substrates by cyanobacteria was studied in Arabian/Persian Gulf by Al-Thukair and Golubic (1991). Most of such relationships between algae and sediment deposition is reported from the marine littorals (Golubic 1976). In such environments, calcareous sediments deposited continuous on the surface of algal mats, and cyanophytes tend to move up through sedimentation (Monty \& Hardie 1976, Golubic 1969).

Apart from the cyanobacteria, a few eukaryotes play an active role in thedevelopment of stromatolitic structures. Examples include diatoms (Winsborough \& Golubic 1987) and charophytes (Martin-Closas 1999). In addition to those inaquatic habitats, there are 'desert stromatolites' capable of surviving in the adverse environmental conditions (Krumbein \& Giele 1979). These findings stress the importance of cyanobacteria in the study of microbial communities and their relationship to calcification.

Little is known about such structures from the freshwater environments, where they do not grow as much as in the marine habitats. Reports of their occurrence from freshwater marshes (Monty \& Hardie 1976) and streams are informative as they show growth similar to algal stromatolites. Golubic (1973) described calcareous deposition leading to the formation of various forms of outgrowths in relation to biotic and abiotic interactions in marine and freshwater stromatolites.

Only a few biologists are concerned with the lotic communities and the ecology of calcareous hard running waters in arid environments (Winsborough \& Golubic1987, Stock \& Ward 1991).

The present paper is a continuation of author's previous work (Hussain et al.1996). It describes various forms of laminated cyanobacterial mats and their respective species composition, structure and stratification in relation to ecology and topography in a lotic setting.

\section{Materials and methods}

\section{- Sample collections}

The hard and encrusted subaerial mats were removed from the side-wall of the canal with the help of a geological hammer and chisel. The thick, submersed mats and thet hinner submersed mats were peeled-off by hand. The submersed mats were difficult to sample because of the water-currents below the slippery drop structures. Samples were stored in zip-locked polypropylene bags either soaked with little original water or air dried.

\section{- Direct and indirect mat investigation}

Emersed and submersed mats were investigated directly in the field with the help of a field microscope followed by a detailed microscopic assessment in the laboratory to record species composition.

Cylindrical cores ( $2 \mathrm{~cm}$ across) of the emersed mats were made with the help of a cork borer, while the subaerial mats were rehydrated and broken with a geological hammer, to observe various stratification.

Subaerial mats were inspected indirectly after conspicuous algal growth appeared in all flasks.

\section{- Microscopy}

Microscopy and photomicrographs were made using a Leitz stereoscope equipped with Wild photomat MPS 55.

\section{- Cultures}

Small pieces of subaerial $(2-3 \mathrm{~cm})$, emersed and submersed mats were inoculated in three sets of media ; original water, BBM (Bischoff \& Bold 1963) and CHU 10 (Chu 1942) to determine algal growth not present in the live samples. The cultures were incubated at $25^{\circ} \mathrm{C}$ and $30^{\circ} \mathrm{C}$, with light of $68.25 \mu \mathrm{E} \mathrm{S}^{-1} \mathrm{~m}^{-2}$ photon rate provided by white fluorescent light source. Cultures were examined after 3-4 weeks following inoculation or as soon as apparent growth was observed.

\section{- Water analysis}

Water sample for analysis was collected from the first drop structure in acid-cleaned polypropylene bottles. Water temperature, conductivity, $\mathrm{pH}$, ammonia, nitrate- $\mathrm{N}$, reactive-P and reactive-Si were measured in the field using a Hach (DR-EL/2) portable spectrophotometer. The remaining measurements were carried out in the laboratory by atomic absorption spectroscopy (Pye Uicam SP 9) and by titrimetric methods. For more details of water analysis see Hussain et al. (1996).

\section{- Study area}

Moshrif (1981) described the geology of the study area as Lower Cretaceous, which is composed of carbonate lithofacies. It includes arenaceous, dolomitic and argillaceous limestones, and chalky and sandy marls. 
The main source of water supply to AI-Kharj irrigation canal is from a deep magmatic underground cavelake. The piedmont underground cave-lake is $c a 100 \mathrm{~m}$ in diameter and $c a 130 \mathrm{~m}$ deep and located south west of Al-Kharj, an agricultural town $\left(23^{\circ} 55^{\prime} \mathrm{N}-47^{\circ} 10^{\prime} \mathrm{E}\right)$. Water is lilted from the cave-lake by electrical pumps to a $16 \times 16 \mathrm{~m}$ pool, from where it flows into a shallow (60-80 cm deep) concrete open canal $(2.4 \times 1.4 \mathrm{~m}$ cross-section throughout its length). The gradual and steep slopes alternate in the course along the first few kilometers of the canal flow, promoting current velocity. Drop structures constructed on the floor of the canal, improves gravitational water-flow, resulting in splash zones, which cause surf formation and aeration of water. These drop structures provide various aquatic habitats. These were studied from November 1996 to October 1997. Figure 1 shows the change in the longitudinal angle of the canal, in longitudinal section at the first drop structure, where the water gushes faster than at any other drop structure.

Four discrete mats types are distributed in three zones : splash, periodically submersed and permanently submersed zone. They are described in a descending order starting from the top to the bottom of the sidewall of the canal.

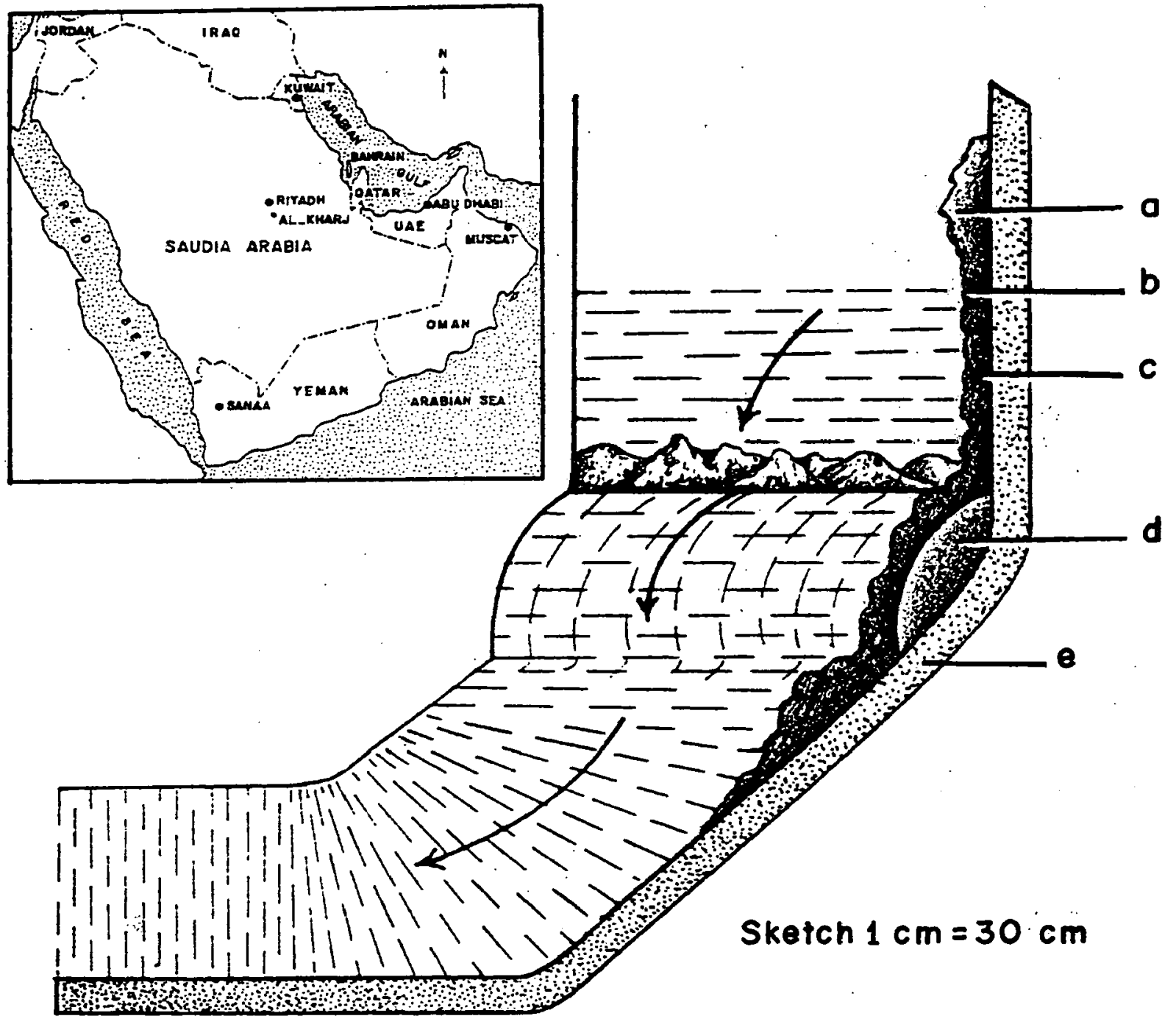

Fig. 1. Longitudinal section of the canal at the first weir (an arrow indicates waterways) showing distribution and abundance of alga mats in the three zones, 'a' subaerial mat (splash zone) ; 'b' emersed mat (periodically submersed) and 'c' submersed mat (permanently submersed). Edge of the weir 'd' dominated by plentiful cone-like mats and juvenile filaments of Phormidium sp. and ' $\mathrm{e}$ ' section of the side-wall of the canal. Inset is a map of Saudi Arabia showing the study area (Al-Kharj).

Fig. 1. Section longitudinale du canal à la première structure de pente montrant la distribution et l'abondance des tapis d'algue dans les trois zones, 'a' tapis subaérien (exposé aux projections) ; 'b' tapis émergé (submergé périodiquement) ; 'c' tapis submergé de façon permanente ; 'd' bord de la rupture de pente dominé par de nombreux tapis en forme de cônes et des filaments juvéniles de Phormidium sp. ; 'e' section de la paroi du canal. 


\section{Results}

\section{- Water chemistry}

Water chemistry was carried out on a monthly basis, but only data for quarterly periods are presented for convenience (Table 1). The $\mathrm{pH}$ varied from 7.8 in November 1996 to 7.9 in July 1997. The major ions showed an increase as $\left(\mathrm{SO}_{4}{ }^{-2}\right.$ from 85 to $120 \mathrm{mgl}^{-1}, \mathrm{Na}^{+}$ from 125 to $201 \mathrm{mgl}^{-1}$ and Si from 8.6 to $12 \mathrm{mgl}^{-1}$ ) with the onset of the summer season. Subsequently, conductivity also increased from 315 to $400 \mathrm{mS} . \mathrm{m}^{-1}$. In contrast, other elements decreased from November to July (Ca from 220 to $210 \mathrm{mg} \mathrm{l}^{-1}, \mathrm{NH}_{4}$ from 0.317 to $0.321 \mathrm{mgl}^{-1}$ and calcium carbonate from 320 to 310 $\mathrm{mgl}^{-1}$ ). Minor elements such as manganese and zinc were present in detectable level during the entire study period.

\section{- Algal mats}

Three major forms of mats were recognised on the bases of their zonal distribution, physical characteristic and species composition. The description of each of the three mats types is given below in a descending order starting from the top to the bottom of the side-wall of the canal.

\subsection{Subaerial mats}

Subaerial mats occupied the splash zone area above the water-level. They produced $c a 50-70 \mathrm{~cm}$ wide belt and were $2-5 \mathrm{~cm}$ thick. The physical texture was lithified (rocky) and nodular in surface appearance. Abundant groups of calcite crystals (travertine, cobbles and sedimentary structures) were observed, which showed marked birefringence under the polarizing microscope. The mat was firmly attached to the side-walls of the canal forming a permanent feature, hard to remove from the solid concrete wall. It was first noticed in 1991. Since then no apparent changes were observed except expansion to cover a larger area.

The development of mat showed an acronodular growth i.e. their accretions of lithified mound-like structures are relatively large $1.5-2 \mathrm{~cm}$ across and $2-4 \mathrm{~cm}$ in depth and tend to grow downward, towards

Table 1. Water chemistry of the Al-Kharj irrigation canal sampled at the first weir on three occasions. Concentration of elements and calcium carbonate as $\mathrm{mgl}^{-1}$.

Tableau 1. Chimie de l'eau du canal d'irrigation prélevée à la première rupture de pente à 3 dates. Concentration des éléments et carbonate de calcium exprimés en $\mathrm{mg} \mathrm{l}^{-1}$.

\begin{tabular}{lccc}
\hline & Nov. 5, 1996 & Mar. 7, 1997 & July 5, 1997 \\
\hline & & & \\
$\mathrm{mS} \cdot \mathrm{m}^{-1}$ & 315 & 350 & 400 \\
$\mathrm{pH}$ & 7.8 & 7.7 & 7.9 \\
$\mathrm{Na}^{+}$ & 125 & 182 & 201 \\
$\mathrm{~K}^{+}$ & 18 & 24 & 32 \\
$\mathrm{Mg}^{2+}$ & 45 & 70 & 75 \\
$\mathrm{Ca}^{2+}$ & 220 & 210 & 210 \\
$\mathrm{Mn}^{2+}$ & 0.01 & 0.14 & 0.07 \\
$\mathrm{Fe}^{2+}$ & 0.14 & 0.11 & 0.18 \\
$\mathrm{Zn}^{2+}$ & 0.031 & 0.091 & 0.081 \\
$\mathrm{NH}_{4}^{+}$ & 0.317 & 0.25 & 0.321 \\
$\mathrm{NO}_{3}-\mathrm{N}$ & 2.1 & 1.1 & 1.1 \\
$\mathrm{SPR}^{-}$ & 0.12 & 0.03 & 0.01 \\
$\mathrm{Si}^{-}$ & 8.6 & 9.8 & 12 \\
$\mathrm{Cl}^{-}$ & 262 & 294 & 357 \\
$\mathrm{CaCO}_{3}$ & 320 & 327 & 310 \\
$\mathrm{SO}_{4}^{-2}$ & 85 & 95 & 120 \\
\hline
\end{tabular}


the water level, from where they receive frequent splashing. In contrast, the accretions $20 \mathrm{~cm}$ above the water-mark, where they receive little splashing are smaller, $0.5-1 \mathrm{~cm}$ across and $1-2 \mathrm{~cm}$ in height. The accretions gradually decrease in the size and in height and finally forms a thin crust $(0.2-0.5 \mathrm{~cm}), c a 60-70 \mathrm{~cm}$ away from the water-mark.

Figure 2 shows surface view of the nodular accretions and the deep incisions $(0.2-0.5 \mathrm{~cm})$ that formed labyrinth of interconnected minute channels through which splash water drains back to the canal. A longitudinal fracture surface of the mat (Fig. 3) shows four discrete coloured strata, the lowest stratum represents a plain surface of white crust by which it adheres to the side-wall of the canal. The middle and upper strata appeared profusely perforated due to fine micropores (porous sediments) formed as a result of transverse microchannels. The degree of perforation was higher in the uppermost stratum. In the middle of these perforated strata, a zone of endolithic cyanobacteria (3-6 mm thick) was apparent.

In cultures biogenic components of the nodular accretions were overwhelmingly dominated by cyanobacteria (Table 2). A few aquatic invertebrates were also observed.

\subsection{Emersed mats}

Emersed mats were periodically submersed and occurred $\mathrm{ca} 8-10 \mathrm{~cm}$ below the subaerial mats and $40-50$ $\mathrm{cm}$ above the submersed mats. Their growth was optimal at the water-mark. Periodic submersion of these mats is a result of fluctuations in water supply from the cave-lake, which cause either receding or increasing in water levels. Being thick and spongy in consistency these mats remain well soaked most of the time.

Two types were recorded from the emersed zone and are classified as cyanobacterial and diatom mats on the basis of the dominant taxa.

\section{a) Cyanobacterial mat}

Mats were found arranged in a gradiental fashion in the upstream particularly, at the first five drop structures. Their maximum growth was found during the winter months from December through February (mean of $25^{\circ} \mathrm{C}$ ). The mat morphology consists of thick $(2-4 \mathrm{~cm})$ floppy and mammilate outgrowths, soft in consistency, the filaments grow in form of bundles making them to appear like a series of small mounds.

The cyanobacterial mats in cross section consists of three to four visually conspicuous strata. The upper most stratum was dominated by an admixture of Chlorophyta and cyanobacteria. In a few instances the green algae were found to be established in a thin layer containing Gongrosira incrustans and Cosmarium sp. Short filaments of Cladophora and/or Spirogyra species were found attached to the surfacial but, were not a part of the mat (Table 2). These two filamentous algae were recorded in abundance downstream and are considered nuisance to the water maintenance. The second stratum was dominated by cyanobacteria. Occasionally a thin layer of golden brown pigments of diatoms was apparent, followed by a stratum of off-white substances consisting of calcite crystals and sediments trapped during mats formation.

\section{b) Diatom mat}

The abundance of jelly-like masses of diatoms were recorded upstream in the splash zone, the maximum growth appeared at the first drop structure, reaching a thickness up to 3-5 cm during the winter months (Dec. -Feb.). The mats were conspicuous because of their discrete brownish colour, characteristic of diatoms.

\subsection{Submersed mats}

Permanently submersed mats are attached to the floor, along the drop structure of the canal. They form mound-like growths especially at the drop structures. They favour high current velocity and sediment-rich influx. Their growth is causing physical hindrance to waterways and are considered nuisance to drainage authority.

This crusty of mat was $0.2-0.5 \mathrm{~cm}$ thick, velvety in consistence and ubiquitous in distribution. The most luxuriant mat occurred in the vicinity of the first three dropstructures. Phormidium tenue was the predominant cyanobacterium although Oscillatoria sp. was also recorded downstream.

\section{- Species composition}

Emersed mats was used start cultures. The two months old cultures kept under emersion-immersion conditions in the original water were dominated by Phormidium tenue. The growth of this cyanobacterium lead to the formation of tufts or cones $(1-2 \mathrm{~cm}$ high, Fig. 4). The cultures of $P$. tenue showed under desiccation conditions white cones, which acquired an encrusted protective cap, composed of halite $(\mathrm{NaCl}$ crystals Fig. 5). Damaged culture, released phycoerythrin and phycocyanin. The tufts and cones retained their normal morphology when rehydrated in the fresh original water. Phormidium tenue emerged as the only species to survive the unfavourable environmental conditions.

\section{- Taxonomic observations}

Thirty eight species were recorded during the present study : 23 cyanobacteria, 2 Chlorophyceae and 

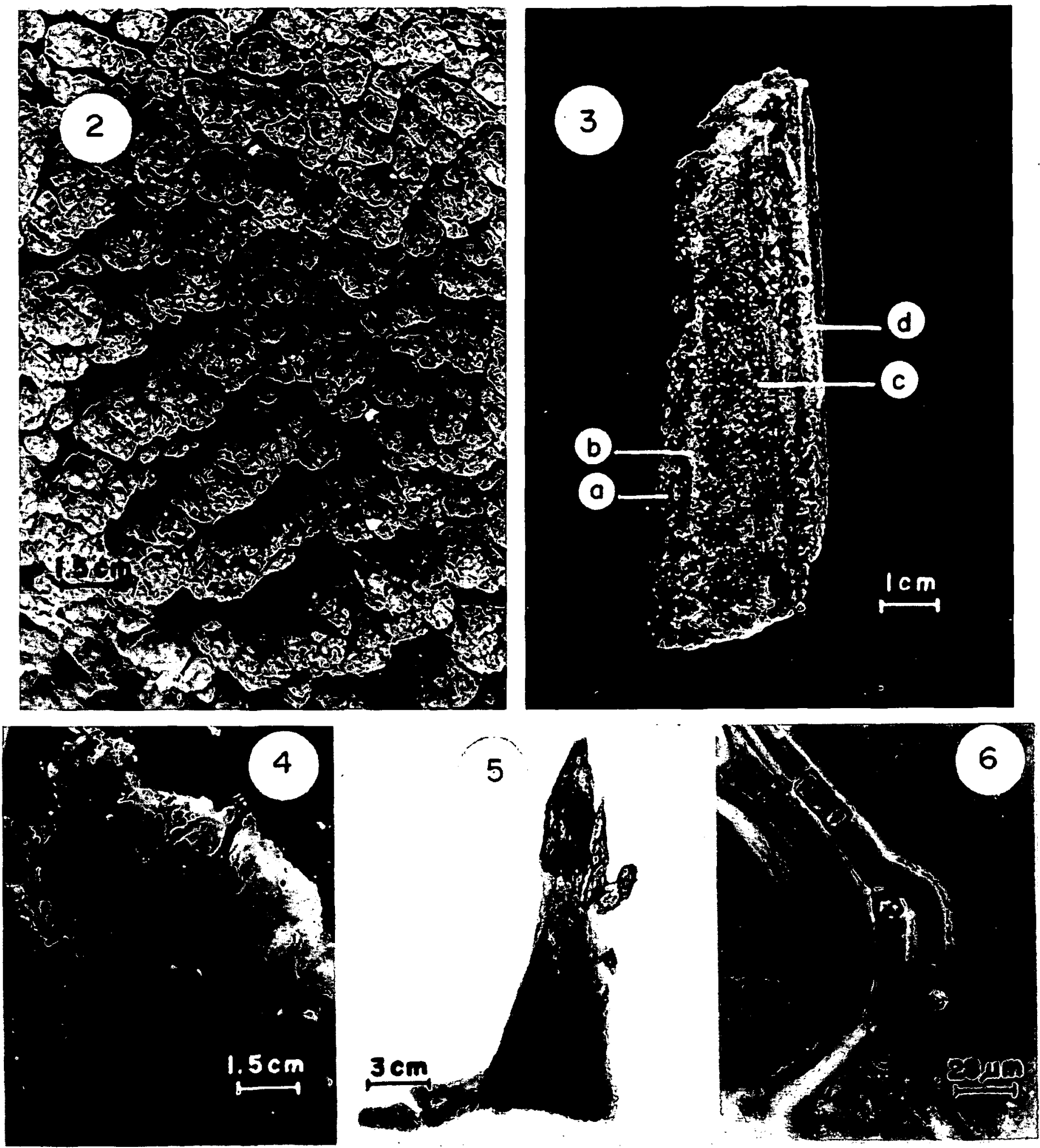

Figs. 2-5. Algal mats of Al-Kharj irrigation canal. 2. Surface view of subaerial mat, showing nodular accretions of calcium carbonate around algal filaments. 3. View of longitudinal fracture surface through the subaerial mat with 4 discrete strata. Nodular accretions on the mat surface seen in side view ' $a$ ' with underlying algal zone ' $b$ ', dense assemblage of perforation in a gray zone ' $c$ ', and the underlying white travertine crust ' $d$ ' by which the mat is attached to the base of the canal. 4 and 5. Phormidium tenue (Menegh.) Gomont. 4. A couple of cones developed in vitro as a result of desiccation and saturation of solute. 5. showing a well-developed cap of white crystalline elements formed in vitro during desiccation.

Figs. 2-5. Tapis d'algues de canal d'irrigation de Al-Kharj. 2. Vue extérieure de tapis subaérien, montrant des formations nodulaires de carbonate de calcium autour des filaments d'algues. 3. Vue d'une coupe longitudinale de tapis subaérien montrant 4 strates. Formation des nodules, 'a' à la surface du tapis avec la couche sous-jacente ; 'b' d'algue ; 'c' assemblage dense de perforations dans une zone grise ; ' $d$ ' couche encroûtante de travertin blanc adhérant au canal. 4 et 5 . Phormidium tenue (Menegh) Gomont. 4. Couple de cônes développés in vitro à la suite de période de dessication et d'humidification. 5. Chapeau bien développé des éléments cristallins blancs formés in vitro pendant la dessication. 
13 Bacillariophyceae (Table 2). The highest number of taxa was found in the emersed mats followed by subaerial and submersed mats. A surprisingly rich flora was recorded from the diatomous masses, consisting of 13 genera of diatoms, seven cyanobacteria and one green alga. The latter was sporadic in distribution. Records of diatoms were based on live and/or cleaned frustules, and the relative abundance of the taxa is not provided. Pennales were dominated over Centrales. It is interesting and striking to note that there is a mixture of taxa (Table 2) which are otherwise known from freshwater and marine environments.

The emersed non-diatomous masses was predominated by non-heterocystous filamentous cyanobacteria. Phormidium tenue comprised of $60-70 \%$ of the mat. The others, in order of decreasing abundance, we-

Table 2. List of algal vegetation recorded from three algal mats (Sa : Subaerial ; Sm : Submerge ; Im : Immerse) in the AlKharj Irrigation Canal. Relative proportions of the various algal taxa are indicated on a $1-5$ scale : 1, rare ; 2, occasional ; 3, frequent ; 4, abundant ; 5, very abundant (see Holmes \& Whitton 1981).

Tableau 2. Liste de la végétation algale récoltée dans trois tapis d'algues (Sa : subaérien; Sm : submergé ; Im : immergé) du canal d'irrigation Al-Kharj. Les abondances relatives des différents taxa sont indiquées à l'aide d'une échelle 1-5:1, rare ; 2, occasionnel ; 3, fréquent ; 4, abondant ; 5, très abondant (cf. Holmes \& Whitton 1981).

\begin{tabular}{|c|c|c|c|}
\hline & Sa & Sm & Im \\
\hline Achnanthes spp. & 1 & 2 & - \\
\hline Aphanocapsa stagnina (Spreng) A. Br & - & 2 & 1 \\
\hline Borzia trilocularis Cohn & - & 1 & - \\
\hline Colothrix parietina Thuret & - & 1 & - \\
\hline${ }^{*}$ Chara spp. & - & - & - \\
\hline Chroococcus minutus (Kütz.) Näg. & - & 1 & - \\
\hline Cladophora glomerata (L.) Kütz. & - & - & - \\
\hline Cocconies sp. & 2 & - & - \\
\hline Cosmarium sp. & - & 2 & - \\
\hline Dichothrix gypsophila (Kütz.) Born. \& Flah & 1 & 1 & - \\
\hline Fragilaria spp. & 1 & 1 & - \\
\hline Gomphosphaeria aponina Kütz. & - & - & 3 \\
\hline Gongrosira incrustans (Reinsch) Smidle & - & 2 & - \\
\hline Lyngbya aestuarii (Mert.) Liebm. & - & 1 & - \\
\hline L. lutea (Ag.) Gomont & - & 2 & - \\
\hline Merismopedia glauca (Ehrenb.) Näg. & - & 1 & 1 \\
\hline Microcoleus chthonoplastes Thuret & 2 & 3 & - \\
\hline Navicula sp. & 2 & 2 & - \\
\hline Nostoc linckia (Roth) B \& F & - & 2 & - \\
\hline Oscillatoria principes Vaucher ex Gomont & 2 & 3 & - \\
\hline Oscillatoria spp. & 1 & 2 & 2 \\
\hline Phormidium incrustatum (Näg.) Gomont & 1 & 3 & 2 \\
\hline Phormidium tenue (Menegh) Gomont & 1 & 4 & 5 \\
\hline Schizothrix sp. & 1 & 2 & - \\
\hline Scytonema sp. & 1 & 2 & - \\
\hline${ }^{*}$ Spirogyra $>36>48 \mu \mathrm{m}$ & - & - & - \\
\hline Spirulina meneghiniana Zanard. ex Gomont & - & 1 & - \\
\hline Tolypothrix distorta Kütz. & - & 1 & - \\
\hline
\end{tabular}

* Recorded in downstream 
re Oscillatoria princeps, Microcoleus chthonoplastes and Schizothrix sp. Two of the heterocystous forms Tolypothrix distorta and Dichothrix gypsophila were infrequently recorded.

In cultures of subaerial mat, the principal filamentous cyanobacterium to first emerge was Tolypothrix distorta, followed by Microcoleus chthonoplastes, Schizothrix sp.,Dichothrix gypsophila and Phormidium tenue. The principal species merits detailed description.

Tolypothrix distorta (Fig. 6) composed of almost monospecific population dominated the subaerial mat, where it was moderately calcium carbonate encrusted, rarely occurred in the emersed, it rarely occurred in the submerged mat nor in the jelly-like masses of diatoms (Table 2). Morphologically, it compares favourably with the description and figures given by Desikachary (1959). However, a few disparities were found from the type material (Desikachary 1959). The present isolate showed infrequent pseudo-branches in the juvenile thalli ; rarely, a few branches occurred midway between two heterocysts (a character of Scytonema) and by having wider trichomes $12-14 \mu \mathrm{m}$ then recorded by Desikachary (1959). The older mat of $T$. distorta which grows from a coherent base was brownish in colour, demonstrated cells andfrequent short pseudo-branches mostly subtending a heterocyst, whic resembled $T$. byssoidea (Berk.) Kirchn. In contrast, the juvenile thalli composed of vertically accelerating bright blue-green bundles demonstrated infrequent and long branches and cells up to 20-24 $\mu \mathrm{m}$ long, similar to $T$. distorta var. penicellata (Ag.) Lemm, but the thallus was not many centimeters long.

\section{Discussion}

The moderately high values of conductivity $(400$ $\left.\mathrm{mS} . \mathrm{m}^{-1}\right)$, sulphate $\left(120 \mathrm{mgl}^{-1}\right)$, sodium $\left(201 \mathrm{mgl}^{-1}\right)$ and magnesium $\left(75 \mathrm{mgl}^{-1}\right)$ as well as calcium carbonate (327 mgl-1) is shown in Table 1. The Al-Kharj water is characterised as brackish. A number of species recorded in the present study viz. Microcoleus chthonoplastes and Lyngbya aestuarii are usually been recorded elsewhere from brackish waters or marine environments. Several taxa which are characteristic of freshwater (Cladophora glomerata, (L.) Kütz, Cosmarium sp, Gongrosira incrustans and Spirogyra sp.) were also present in Al-Kharj canal. Nevertheless, the present account of identification (Table 2) was made irrespective of the habitats.
Algal growths were recorded in all transect studied, with majority of the species found in the emersed mat (Table 2). The basal zone of the emersed mat was frequently characterised by black stains formed due to anaerobic conditions and degeneration of algal community, thus smells of hydrogen sulphide. The thicker $(4-5 \mathrm{~cm})$ and older mats detach from the basal cementing substratum under their own weight because of the regular degeneration and degradation process beneath them.

Golubic (1973) described three conditions for $\mathrm{CaCO}_{3}$ precipitation, in reference to the upper, intermediate and lower flow of a river system, in which the precipitation of $\mathrm{CaCO}_{3}$ was spontaneous in the upper flow. Similar phenomenon was observed in the present study. Most of the area of the side-wall of the canal was occupied by the subaerial mat (Fig. 2), the luxuriant growth was predominant in the upper flow and above the water-mark, presumably due to splashing by fast water-current. The fluvial ecosystem of the canal is in agreement with the description given by Golubic (1973) for sediment formation in running waters.

The formation of subaerial mat have resulted from a combination of the gelatinous matter produced by cyanobacteria, early development of algal fabrics spread over loose sediment followed by deposition of carbonate from abiotic and biotic processes. Sediments brought by the wind (sandstorms) into the canal (Hussain et al. 1996) and trapped by the mat at the drop structures further increased sedimentation. The sidewalls of the canal above the water-mark (Fig. 1) kept moist by the spray provided a favourable substratum for sediment trapment and colonization by cyanobacteria. The interaction of these abiotic and biotic factors lead to a gradual development of a stratified mat with nodular accretions of calcium carbonate, which remains as a permanent feature of the canal and cause nuisance for the water flow maintenance.

The maximum amount of tufa being deposited at the first drop structure is due to the active role in calcite deposition by a number of cyanobacteria (Table2). Geitler (1932) described that conspicuous population of Dichothrix and Rivularia are common in sites where tufa deposition occurs. However, in the present study, Tolypothrix distorta was the predominant cyanobacterium.

The over two months old cultures of Phormidium tenue demonstrated a typical growth morphology in the form of tufts or cones with the development of crystallization of halite (Figs $4 \& 5$ ), in response to saturation of solute during desiccation. The capping of halite seems to play an important role in preventing the juve- 
nile trichomes from direct exposure to excessive sunlight, and may acts as a shield against the grazing invertebrate. The crystallization of gypsum and halite is very common in marine cyanobacteria (Golubic 1973,1976 , Braithwaite \& whitton 1987) but, it is not known from running waters (Golubic 1973, Winsborough \& Golubic 1987, Stock \&Ward 1991).

Calcium carbonate encrusted jelly-like assemblage of diatoms in the escarpment of the splash zone characteristic by the white to light yellow colours was composed of several species of diatoms and a few species of cyanobacteria (Table 2). The role of diatoms in stromatolitic growth in the freshwater settings was described by Winsborough \& Golubic (1987). They described characteristic domed shaped stromatolitic growth composed of a few cyanobacteria and the predominant genera of diatoms viz. Gomphonema, Amphora and Cymbella. Two of the latter genera were also recorded in the present study, suggesting the likelihood that similar growth forms of domes could be found in the Al-Khaki canal. Further attention is required in subsequent study to determine the dome-shaped growth morphology and the role of diatoms in stromatolite growth in the arid environment, with special significance to water chemistry.

The Al-Kharj subaerial mat resembles an extant stromatolite, and is in agreement with the definition given for stromatolite by Walter (1976) as well as with the rocky and nodular morphology given by Preiss (1976). Stromatolites were reported from marine and hypersaline habitats (Golubic 1973, Kendall \& Skipwith 1968) and less commonly from brackish and freshwaters (Black 1933), like e.g. the cushion-like structures produced by Scytonema in the brackish ponds of Andros Island, Bahamas.

Microbial mats in the aquatic environments of arid region grow abundantly irrespective of increased temperature and evaporation. They are subjected additional dynamic changes, such as the increase in ionic concentration, mineral precipitation, sedimentation and desiccation. Under these harsh conditions, a few species survive and dominate (Hussain \& Khoja 1993). The three most tolerant species to face such adverse conditions encountered in the present study are Tolypothrix distorta, Phormidium tenue and Microcoleus chthonoplastes.

"Because the growth of endolithic microorganisms within a lithified carbonate substrate presents serious limitations for their direct study" (Golubic 1973 : p. 468) cultures were started from subaerial mats and grown in various media, including the original environmental water in order to determine algae which we- re not present in the mats at the time of collection. The principal alga to appear first in most of the cultures was Tolypothrix distorta. It is interesting to note that juvenile trichomes (not shown in Fig. 6) of $T$. distorta had cells longer $(20-24 \mu \mathrm{m})$ than wide as a possible adaptation to win the race with sediment trapping and precipitation rates. Whitton et al. (1986) described a number of blue-green algae responsible for surface morphology in a tufa depositing site at Al-Tanoumah waterfall. There Scytonema myochrous (Dillw.) Ag and Dichothrix gypsophila were represented in a splash zone caused by a waterfall. The growth-form of the $S$. myochrous resulted in flattened domes, comparable to the Tolypothrix distorta nodular accretions described here. The cyanobacterium D. gypsophila was represented at both sites. These species characterised by firm, fibrous texture are the binding force in the mat development, whereas coccoid species further provide mucilaginous and cementing substratum (Krumbein \& Giele 1979), these together help in trapping of sedimentary grains. In conclusion, different ecological conditions prevailing in marine and non-marine settings promote development of similar organosedimentary structures under the guidance of cyanobacterial mats.

\section{Acknowledgments}

I greatly appreciate the help of S. Golubic (U. S. A.) for his critical comments, suggestions and improvement of the manuscript. Thanks are also due to $M$. I. Hussain for collecting samples and for his suggestions and comments.

\section{References}

Al-Thukair A.A. \& Golubic S. 1991. - New endolithic cyanobacteria from the Arabian Gulf 1. Hyella immanis sp. nov. J. Phycol., 27 : 766-780.

Black M. 1993. - The algal sediment of Andros Island, Bahamas. Phil. Trans. R. Soc. Lond. B., 222 : 165-192.

Bischoff H.W. \& Bold H.C. 1963. - Phycological Studies. IV. Some algae from Enchanted Rock and related algal species. Univ. of Texas Pub., No.6318 : 95 p.

Braithwaite C.J.R \& Whitton B.A. 1987. - Gypsum and halite associated with the Cyanobacterium Entophysalis. Geomicrobiol. J., $5: 43-54$.

Chu S.P. 1942. - The influence of mineral composition of the medium on the growth of planktonic algae. I. Methods and culture media. J. Ecol., 30 : 284-325.

Desikachary T.V. 1959. - Cyanophyta. Indian Council Agric. Research. New Delhi : 686 p.

Geitler L. 1932. - Kryptogamenflora von Deutschland, Osterreich und der Schweiz, 14. Cyanophyceae. Akademische Verlagsgesellschaft, Leipzig : $1196 \mathrm{p}$.

Golubic S. 1969. - Distribution, taxonomy, and boring patterns of marine endolithic algae. Am. Zool., 9 : 747-751.

Golubic S. 1973. - The relation between blue-green algae and carbonate deposits. In : N.G. Carr \& B.A. Whitton (eds.) The biology of blue-green algae, Blackwell Scientific Publications, London. Botanical Monographs, $9: 434-472$. 
Golubic S. 1976. - Taxonomy of extant stromatolites-building Cyanophytes. In : M.R.Walter (ed.) Stromatolites. Developments in Sedimentology, 20. Elsevier, Amsterdam, Oxford, New York : 127-140.

Golubic S \& Focke J.A. 1978. - Phormidium hendersonii Howe : identity and significance of a modern stromatolite building microorganism : J. Sed. Petrol., 48 : 751-754.

Holmes N.T.H. \& Whitton B.A. 1981. - Phytobenthos of the River Tees and its tributaries. Freshwat. Biol., 11 :138-168.

Hussain M.I. \& Khoja T.M. 1993. - Intertidal and subtidal bluegreen algal mats of open and mangrove areas in the Farasan Archipelago (Saudi Arabia), Red Sea. Bot. Mar., 36 : 377-388.

Hussain M.I., Khoja T.M. \& Guerlesquin M. 1996. - Chemistry, ecology and seasonal succession of Charophytes in the Al-Kharj irrigation canal, Saudi Arabia. Hydrobiologia, 333 :129-137.

Kendall C.G.St. C. \& Skipwith P.A. d'E. 1968. - Recent algal mats of a Persian Gulf lagoon. J. Sed. Petrol., 38 : 1040-1058.

Khoja T.M. 1987. - New records of marine algae for the coast of Saudi Arabia. Bot. Mar., 30 : 11-19.

Khoja T.M. 1993. - Water composition and filamentous algae in the irrigation and drainage networks of Al-Hassa Oases, Saudi Arabia. Crypt. Bot., $4: 1-7$.

Khoja T.M. 1998. - New records of open and mangrove algae on the Saudi Coast of the Arabian Gulf. Nova Hedwigia, 67 : 153-168.

Krumbein W.E. \& Giele C. 1979. - Calcification in a coccoid cyanobacteria associated with the formation of desert stromatolites. Sediment, 26 : 593-604.
Martin-Closas C. 1999. - Epiphytic overgrowth of charophyte thalli by stromatolite-like structures and flungi in the lower cretaceous of the Iberian Ranges (Spain). Aust. J. Bot., $47: 305-313$.

Monty C.L.V \& Hardie L.A. 1976. - The geological significance of the freshwater blue-green algal calcareous marsh. In : M.R. Walter (ed.) Stromatolites. Elsevier Scientific, Amsterdam : 447-477.

Moshrif M.A. 1981. - Sedimentation and palaeography of the Buwaib formation (Lower Cretaceous) in Central Saudi Arabia. J. Coil. Sci. Univ. Riyadh, 12 : 205-231.

Preiss W.V. 1976. - Basic field and laboratory methods for the study of stromatolites. In : M.R. Walter (ed.) Stromatolites. Development in Sedimentology, 20. Elsevier, Amsterdam, Oxford, New York : 6-13.

Stock M.S \& Ward A.K. 1991. - Blue-green algal mats in a small stream. J. Phycol., $27: 692-698$.

Walter M.R., Bauld J. \& Brock T.D. 1976. - Microbiology and morphogenesis of columnar stromatolite (Conophyton, Vacerrilla) from hot springs in Yellowstone National Park. In : M.R.Walter (ed.) Stromatolites. Development in Sedimentology, 20. Elsevier, Amsterdam, Oxford, New York : 273-336.

Whitton B.A., Khoja T.M. \& Arif I.A. 1986. - Water chemistry and algal vegetation in the Asir Mountains, Saudi Arabia. Hydrobiologia, $133: 97-106$.

Winsborough M.B. \& Golubic S. 1987. - The role of diatoms in stromatolite growth : Two examples from modern freshwater settings. J. Phycol., 23 : 195-201. 